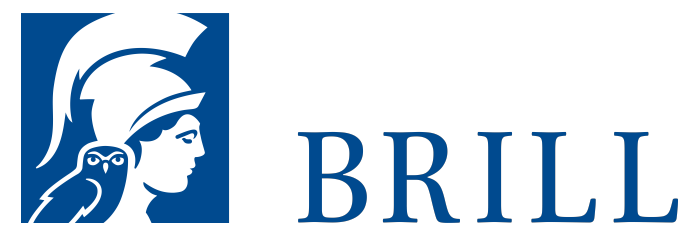

\title{
Selbsttäuscherische Hoffnung
}

Eine sprachanalytische Annäherung

Author: Roland Bluhm

Ein Leben ohne Hoffnung, so will es eine verbreitete Intuition, ist nicht lebenswert - wenn ein Leben ohne Hoffnung überhaupt möglich ist. Der landläufigen Ansicht nach ist Hoffnung ein Gut. Doch dass die Dinge nicht so einfach liegen, zeigt sich bereits an der ältesten abendländischen Geschichte zur Hoffnung, dem Pandoramythos bei Hesiod. Der Mythos stellt Hoffnung als Übel dar, als Teil einer Strafe, die Zeus den Menschen auferlegt. Diese Wertung der Hoffnung widerspricht der Intuition vieler Interpreten und war Anlass, den Mythos in verschiedenster Weise so zu interpretieren, dass Hoffnung nicht mehr als Übel dasteht. Hoffnung kann jedoch in vielerlei Weise defizitär sein. Wir sprechen etwa davon, dass Hoffnungen täuschen oder trügen. In harmlosen Fällen heißt das nicht mehr, als dass sich diese Hoffnungen nicht erfüllen und zu hoffen daher aussichtslos wäre. In weniger harmlosen Fällen wirft man dem Hoffenden vor, er müsste selbst wissen, dass seine Hoffnung sich nicht erfüllen werde, und habe sich nur durch seinen Wunsch, das Erhoffte möge eintreten, zu dem Glauben verführen lassen, es könne eintreten. Ein solcher Vorwurf ist keineswegs abseitig, Hoffnung steht in einem kontingenten, doch engen Zusammenhang mit Selbsttäuschung. Hoffnung beinhaltet einen Wunsch nach dem Erhofften und trägt damit die Motivation in sich, die Aussichten auf das Eintreten des Erhofften...

See More

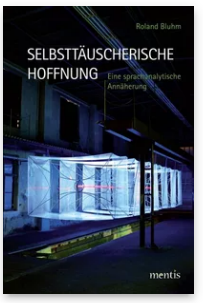

Pages: 280

Seiten

Language:

German

Subjects:

General,

Philosophy

Publisher: Brill | mentis

E-Book (PDF)

Released online:

o1 Oct 2012

ISBN: 978-3-

95743-963-5

List price

USD $\$ 63.00$

Paperback

Publication date:

o1 Oct 2012

ISBN: 978-3-

89785-773-5

List price

USD $\$ 63.00$ 
For more information see brill.com

Order information: Order online at brill.com +44330 333 0049 | customerservices@brill.com Submission information: brill.com/authors

Titles published by Brill | Fink, Brill | mentis or Brill | Schöningh: +49(o)715413279216| brill@brocom.de 